\title{
The Strategy of Radio Convergence For Facing New Media Era
}

\author{
Nur Aini Shofiya Asy`ari \\ nurainishofia@unida.gontor.ac.id \\ University of Darussalam Gontor
}

\begin{abstract}
Radio mainstream media that the listenership drop in a years. In 2015, the listenership radio only about $14 \%$ and frequently reduce to $11 \%$ in 2016 . Today, society prefer to use their gadget as their information media, internet and social media become the most important part of society. Realizing this phenomena, mainstream media industry especially radio synergize with new media. Creating radio station application on gadget, making website, radio streaming, video streaming and social media account, as a way or strategy which is known by media convergency. This research aims to know how media convergency strategy uased by radios in Ponorogo, the form of new media that is used, how the management and to know the opportunity and challenge. This research use qualitative approach. This reaearch also analyze the previous data that obtained from field observation at radios in Ponorogo, then it is reviewed using Communication Science and Media Convergence review theory. The result of this research showed that there are five radios in Ponorogo have already done radio convergency, media convergency strategy has been done using several new media form which integrated to radio broadcast activity, management of media convergency is far from good, thus it is facing several problems. It is expected the result of this research can be contribute to media science and convergency and radio bradcasting effort.
\end{abstract}

Keywords: Radio, Convergency, New Media.

\section{Introduction}

The falling of mainstream media industry is because they can not adapt with the changing habit of society information consumption that already spread. It almost can be counted by fingers the paper based printed media industry which still survive until today. In average, most of printed media bankrupt and transformed to online news cites. It also occurs to television industry and radio industry. The radio advertisement shopping reduced form day to day. People who listened to radio also went down. Listenership decrease from these years. Based on media data habit, AC, Nielsen known that radio listenership fell to $15,77 \%$ in 2015, it is contradictive with internet trend which in $37.845 \%$.

The emergence of new media based internet that follow people habit changing in using media, it caused to the falling of mainstream printed, audio, or visual media industries. As a result, this case caused new condition where maintream media transformed, using new media or collaborate with new media, this condition called as media convergency.

Paper based printed media through convergence moved to online media cites (paperless). The television also implement new media in their bradcasting activity which are website and youtube. It also happened to radio that used new media, they are website, radio streaming, social 
media, and etc. The steps known as media convergency. Radio media convergency was done in almost all radio stations in Indonesia. However the form and target of convergency strategy is different from one radio station to others. Thus, the researcher interested in writing about how media convergency strategy done by radio stations in Ponorogo.

This research is an output of Penelitian Dosen Pemula Hibah DIKTI 2018 with the title "Analisa Penerapan Konvergensi Media Pada Radio di Ponorogo" and it is expected it can be contribute to the develoment of media literature specificly media convergence.

\section{Methods}

Research method used in this research was descriptive qualitative method used primary and secondary sources[1]. Primary sources obtained from interview result which intended for decision maker or people who take media convergency strategy. Structured interview is interview using interview guide and it is already sistematically ordered and complete for data collection.

Secondary data obtained through written document whis is formal handout or book. The function of document as secondary data is to help verify correct spelling, title and name from organizations or term used in the interview. Besides, document able to adding other details for supporting information from other sources[2].

The steps done by the researchers in conducting research with the title Radio Convergence Strategy in Ponorogo in Facing Modern Era were as follows: in deciding research subjects, researchers done the observation to East Java Indonesian Broadcasting Commission (KPID Jawa Timur) to know radios in Ponorogo which officially registered. Then, the researchers focus on doing observation on media convergency strategy by radios in Ponorogo appropriate with the data from KPID Jawa Timur. The observation was done by the researchers toward radios in Ponorogo was about how they conduct convergency, the form of convergency, the usage and management of new media. After that, obtained data then analyzed using convergency media reviewed literature.

\section{Results}

\subsection{Radio Broadcasting}

The first radio station appeared when a mechanic expert named Frank Conrad in Pittsburg US in 1920 as his hobby, he buit a radio tower in his garage. Conrad broasted songs, announce the sport match score and music instrument which played by his son. In short period, Congrad suceed got a lot of listeners in line with the rise of radio tower selling these days. The name of Congrad radio station was KDKA and it is the oldest radio station in US or even in the world.

National Broadcasting Company (NBC) is the first company that built radio network system in 1926. NBC offered program to several radio stations in some areas which want to be their network members. Thus, several radio stations connected each others so it make a network.

The radio stations started to produce their own program and concentrated to get advertisement from local advertisement. Many experiments were done by radio station, one of them in Midwest United States that observed album selling volume in several album shops and then they played songs which most bought by people in their radio station. The result of this 
experiment was great. The listeners love the songs broadcasted and it created the fist radio station format 'Top 40'. The suceed of this experiment created several others broadcasting format and they also success. Broadcasting format of Top 40 adopted by many radio stations in the world included Indonesia.

\subsection{CMC (Computer Mediated Communication) Theory}

Computer has been mediator for people to be able to communicate and interact with the other computer users in different place in the same time called Computer Mediated Communication (CMC) or communication which is mediated by computer. In this context, Computer Mediated Communication (CMC) seen as computer integrated technology with our daily life. As John December said that CMC is interaction between people through computer technology and related each other in the process of forming media for various purposes [3].

According to Joseph Walther and Malcoms Parks, there are many internet technologies form which tend to attract in CMC, they are email, mailing list, weblog, and instant messaging [3]. Internet can be seen as mass media that adding relation one-to-one (applied through e-mail), many-to-many (applied to listservice), and many-to-one (based blog corporate website ). In other words, internet as mass media already help explaining several aspects of events using online. Several form of popular new media are website and social media.

\subsection{Media Convergence}

Media convergency is incorporating or integrating medias to be used and lead to one certain goal point[4]. Media integration is common to be used in the development of digital technology, text integration, number, picture, video and audio. Media convergency is not only technology shift but also shift in industry paradigm, culture, and social which encourage consumers to seek for new information. This is in line with Henry Jenkins in Convergency Culture 'Where Old Media and New Media Collide', that media convergency is a process which occurs suitable with culture development in the society and influenced by media technology[4].

Media convergency according to Henry Jenkins; Content flow in several media platform, cooperation among several media industries and habit migration of media society.

Meanwhile, Terry Flew in An Introduction to New Media define media convergency as the result from three elements of new media which are, communication network, information technology, and media content[5]. This statement is known as 3C concept: computing, communication and content.

The keywords from convergency is digitalization, it is because all form of information or data changed from analog format to digital and sent in bit (binary digit) unit. Since information which sent is digital format, convergency leads to products creation which applicable and able to do audiovisual function and computing at once. As the example, today computer can be used as television or cellphone and it can receive audio, text, data or three dimention (3D) picture.

The nature of radio is only auditory and it has several drawbacks, however by media convergency it is expected to minimalize those radio drawbacks. The form of radio media convergency is as follows; website, radio on demand, radio streaming, video streaming, android application and social media. Social media has the importance to be used in media convergency because people nowadays in their daily life can not separated from social media. People seeking for information, product, exchange ideas and make social movement through social media. Thus, if radio broadcast person is able to be the part of society's life, social media is expected to influence people's habit to listen to the radio[6]. 
From the result of the data obeservation, there are 2 private broadcast isntitutions and 4 community broadcast institutions in Ponorogo which are officially registered in KPID Jawa Timur. Therefore, in this research the researchers done the observation on those six radios. The six radios are Gema Surya Radio, Duta Nusantara Radio, Sulamul Huda Radio, Generasi Bangsa (Gerbang) FM Radio, Shakuntala Radio and Matrix Radio.

Moreover, from those six radios the reserchers conducted observation of media convergency strategy activity. It is known that from 6 registered radios, only one radio which not applied media convergency, it is Shakuntala FM. Furthermore, the research subjects only focused on five radios that officially registered in KPID Jawa Timur. Following are the observation result in the form of new media that applied by five radios in conducting media convergency.

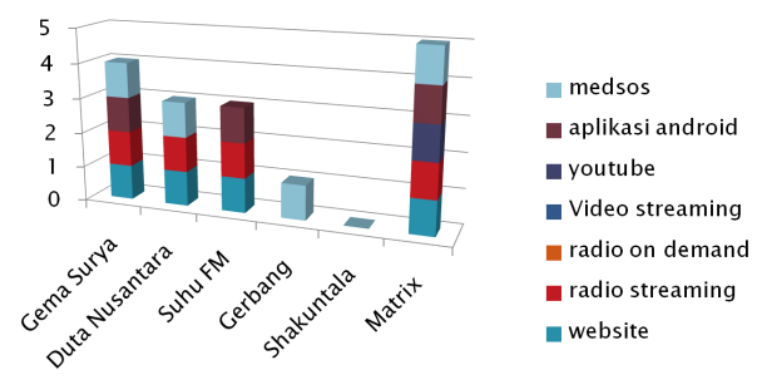

Fig.1 New Media Form Applied by Radios in Ponorogo While Conducting Media Convergency Strategy

To be more detail, the researchers observed the social media used by research subjects in conducting media convergency. These five radios in Ponorogo have already applied media convergency strategy with used several new media form. The most popular new media used were website and radio streaming, it used by four of five radios. Then, social media and android application was the new media form which often used by three of five radios in Ponorogo that conducted media convergency. Social media used was varied, from five social media form, the most popular accessed by people were facebook, twitter, whatsapp, and instagram.

Media convergency is necessity for radio mainstream media in facing new media era. The appearance of new media no to be opposed, but it can be an opportunity for radio mainstream media to maintain their position. According to Errol Jonathan, the Director of Suara Surabaya Media that new media can be a new way for radio broadcast product that teh main target is to bring back people to listen to the radio[7]. Thus, radio broadcast institution should conduc media convergency and understand how the effective way in selecting new media form which used and how to manage it.

However, these five radios in Ponorogo were not so. Some of them admitted that what they are they doing is only to follow the development of technology and information. Even they did not know what media convergency is. Sulamul Huda (SUHU radio) radio management (radio community for boarding school) admitted that during these 3 years they used new media to reach out the boarding school graduates who are out of town. It is expected by using new media, boarding school information can be accessed by boarding school graduates. In line with SUHU FM, Gerbang FM radio also use facebook and whatsapp only to follow the development of technology. However, they also did not know about media convergency. But there are also 
radios that understand media convergence strategies. Gema Surya radio using almost all of new media to convergence. Arif Mashudi as a program staff of Gema Sury radio admitted that Gema Surya radio are trying to rise up by using media convergency strategy. According to Arif, the obstacles faced by Gema Surya radio now is the limited human resources and IT maintenance.

\section{Conclusion}

The summary of this research are; There are five radios in Ponorogo that have been applied radio convergency, although not all understand that the effort of new media usage which is synergized with radio broadcat is media convergency strategy. Media convergency strategy that has been done were using several new media form which integrated with radio broadcast activity. They used varied social media, from five social media, the most popular accessed by the people were facebook, twitter, whatsapp, and instagram. But, the management of media convergency that has ben done is not good yet because the convergency was not treated specially and focus. As a result, several problems faced in conducting media convergency, such as the quality and quantity of human resources, the availability of convergency technology and minimum maintenance, and there was no research about changing habit of people in accessing media. Therefore, knowing the benefit of media convergency that can support radio sustainability, the radios should conducted media convergency maximally and focus to the management. The most important aspect in media convergency strategy maintenance is human resources management, the availability of good convergency technology, IT maintenance and research about media habit.

\section{References}

[1] Sugiono, Metode Penelitian Kuantitatif, Kualitatif, dan R\&D. Bandung: Alfabeta, 2016.

[2] L. J. Moleong, Metodologi Penelitian Kualitatif. Bandung: Remaja Rosdakarya, 2004.

[3] A. C. T. Lengel and L. Tomic, Computer Mediated Communication : Social Interaction and The Internet. California: Sage Publications, 2004.

[4] H. Jenkins, Convergence Culture Where Old and New Media Collide, 3rd editio. Oxford University Press, 2014.

[5] T. Flew, New Media An Introduction, 3rd editio. Oxford: Oxford University Press, 2014.

[6] O. Blanchard, Social Media ROI. Jakarta: Jakarrta, 2015.

[7] N. A. S. Asy'ari, "Konsep Triple Suara Surabaya Dalam Menghadapi Era Media Baru," Universitas Dr. Soetomo Surabaya, 2016. 